\title{
Emerging role of human polyomaviruses 6 and 7 in human cancers
}

Faisal Klufah ${ }^{1,2}$, Ghalib Mobaraki ${ }^{1,3 \dagger}$, Dan Liu ${ }^{1,4+}$, Raed A. Alharbi², Anna Kordelia Kurz ${ }^{5}$, Ernst Jan M. Speel ${ }^{1}$, Véronique Winnepenninckx ${ }^{1}$ and Axel zur Hausen ${ }^{{ }^{*}}$ (D)

\begin{abstract}
Background: Currently 12 human polyomaviruses (HPyVs) have been identified, 6 of which have been associated with human diseases, including cancer. The discovery of the Merkel cell polyomavirus and its role in the etiopathogenesis in the majority of Merkel cell carcinomas has drawn significant attention, also to other novel HPyVs. In 2010, HPyV6 and HPyV7 were identified in healthy skin swabs. Ever since it has been speculated that they might contribute to the etiopathogenesis of skin and non-cutaneous human cancers.

Main body: Here we comprehensively reviewed and summarized the current evidence potentially indicating an involvement of HPyV6 and HPyV7 in the etiopathogenesis of neoplastic human diseases. The seroprevalence of both HPyV6 and 7 is high in a normal population and increases with age. In skin cancer tissues, HPyV6- DNA was far more often prevalent than HPyV7 in contrast to cancers of other anatomic sites, in which HPyV7 DNA was more frequently detected.

Conclusion: It is remarkable to find that the detection rate of HPyV6-DNA in tissues of skin malignancies is higher than HPyV7-DNA and may indicate a role of HPyV6 in the etiopathogenesis of the respected skin cancers. However, the sheer presence of viral DNA is not enough to prove a role in the etiopathogenesis of these cancers.
\end{abstract}

Keywords: HPyV6, HPyV7, Merkel cell polyomavirus, Oncogenic viruses, Cutaneous tumors, Viral persistence, Tumor virus

\section{Background}

Polyomaviruses (PyV's) comprise a family of nonenveloped viruses containing a small genome of approximately $5.0 \mathrm{kbp}$ in size of circular double-stranded DNA and are capable of infecting mammals and birds [1-3]. PyV's are strongly oncogenic in heterologous animal models, suggesting that next to human also non-human polyomaviruses could possibly play a role in human cancers [4-7]. To date, fifteen novel PyV's have been isolated from different human specimens [8]. In 2019, the International Committee on Taxonomy of Viruses

\footnotetext{
* Correspondence: axel.zurhausen@mumc.nl

${ }^{+}$Ghalib Mobaraki and Dan Liu contributed equally to this work.

${ }^{1}$ Department of Pathology, GROW-School for Oncology \& Developmental Biology, Maastricht University Medical Centre+, Maastricht, the Netherlands Full list of author information is available at the end of the article
}

(ICTV) reported only twelve human polyomaviruses (HPyVs) after having HPyV12 excluded, which was shown to be infecting shrews $[9,10]$. In addition, the Lyon IARC polyomavirus which initially was isolated from human skin swab in 2017 is also found in cats feces [11]. Recently in 2019, Ondov et al. isolated the Quebec PyV from a stool sample of one patient through the MinHash algorithm [12]. Yet it still has not been listed as a human polyomavirus by the ICTV [9]. Six of the identified HPyVs have been associated with human diseases, including cancer $[3,8,13,14]$.

In 2008, Merkel cell polyomavirus (MCPyV) has been linked to the etiopathogenesis of the majority (i.e. 80\%) of the highly aggressive neuroendocrine Merkel cell carcinoma (MCC) [15-17]. Already in $2012 \mathrm{MCPyV}$ has been categorized as a group $2 \mathrm{~A}$ carcinogen by the 
International Agency for Research on Cancer (IARC) [18]. MCPyV has also been detected in non-neoplastic $B$ cells (e.g. reactive hyperplasia and normal lymph node) and neoplastic B cells (e.g. chronic lymphocytic leukemia cells,) suggesting a role for $\mathrm{MCPyV}$ in B-cell neoplasias [15, 19-22].

In 2010, HPyV6 and HPyV7 were identified from healthy skin swabs using the rolling circle amplification technique [23]. The HPyV7 genome shares approximately 68\% sequence identity with HPyV6 [23]. As these novel HPyVs were discovered in the skin, their presence in the skin and non-cutaneous human cancers, similar to MCPyV has been studied intensively [24-31]. Additionally, HPyV6 and 7 proteins have been suggested to play a key role in the binding and deactivation of p53 [32]. The oncogenic role of HPyVs in general has been reviewed extensively $[3,7,13,33-36]$. By reviewing sero-epidemiological and tumor-pathological evidence, we here focus on the possible oncogenic role of HPyV6 and 7 in human cancers, and in particular their direct or indirect contribution to tumorigenesis.

\section{Seroprevalence of HPyV6 and HPyV7 in healthy individuals}

Several studies have assessed HPyV6 and HPyV7 serum antibody levels across a broad range of age groups of various populations [23, 37-41]. In 2010, 95 sera from blood donors were tested for the seroprevalence of HPyVs and revealed higher seropositivity for HPyV6 (69\%) than HPyV7 (35\%) using direct enzyme-linked immunosorbent assays (ELISA) directed against virus-like particles (VLP) based on viral protein 1 (VP1) capsid [23]. Likewise, by using ELISA against VP1-VLP, another study estimated the seroprevalence of age groups ranging from 20 years and older and concluded that the prevalence of HPyV6 increased with age and was higher than that of HPyV7 (80-92\% vs $60-80 \%$, respectively) [37]. The HPyVs seroprevalence of 1050 Dutch blood donors aged from 18 to 69 was determined and showed that the prevalence of both viruses increased with age, with 84 and $72 \%$ seropositivity for HPyV6 and HPyV7 VP1 antibodies, respectively [38]. Nicol et al. assessed the seroprevalence of both viruses in 828 subjects across different age groups starting from age one using VLPbased direct ELISA. Their study found that HPyV6 (76\%) was more prevalent than HPyV7 (53\%) across all age groups [39]. Noteworthy, by performing Luminex xMAP technology to detect VP1antibodies for both viruses were detected in the early infancy group up to an age of 6 months with high frequency (80.1\% for HPyV6 and $58.1 \%$ for HPyV7, respectively). On the other hand, a decline in the prevalence of both viruses was found for children age 6 months to 14 years old group [40].
Altogether, both HPyV6 and 7 were found to be ubiquitous and to infect all age groups, and HPyV6 seroprevalence is slightly higher than HPyV7. Seroprevalence significantly increases with age, and a substantial proportion of individuals 50 years of age and older has tested positive for HPyV6 and HPyV7. Approximately 52-93\% of humans are seropositive for HPyV6, whereas 33-84\% are seropositive for HPyV7 according to the seroprevalence studies Table 1 [23, 37-40, 42, 43]. Summarizing the overall age-specific seropositivity of HPyV6 and HPyV7 using ELISA or Luminex platform-based method was shown in (Fig. 1).

In general, HPyV6 and 7 infections seem to be clinically rather asymptomatic, irrespective of the age at which the infection occurs. Increasing seroprevalence of these viruses is clearly age-related and reaches its peak in individuals beyond 40 years of age, possibly indicating a relationship of HPyV6 and 7 infections with immunosenescence. Regarding the methodology, the previous studies reported the seroprevalence of HPyV6 and HPyV7 in the sera obtained from blood donors or routine lab tests in various studies. Most of the studies used ELISA or Luminex platform antibody-binding assay methods to detect the antigen containing the structural viral capsid protein of the targeted viruses fused with VLP or glutathione S-transferase (GST) proteins Table 1. Moreover, one study assessed the agreement and sensitivity of both VLP and GST-based ELISA methods in detecting seropositivity [37]. The results showed only minor discrepancies in the seroprevalence comparing these two detection methods [37]. Kamminga et al. reported high seropositivity of HPyV6 and 7 by using a Luminex xMAP assay directed against the VP1 capsid of HPyVs, similar to other ELISAbased studies [37, 39-41].

\section{Seroprevalence of HPyV6 and HPyV7 in cancer patients}

Only a very limited number of studies have reported seroprevalence data of HPyV6 and 7 in cancer patients. Madeleine et al. recently reported that the seroprevalence of HPyV6 in immunosuppressed skin cancer patients (59.1\%) was lower compared to healthy controls (66.2\%), whereas the seroprevalence of HPyV7 in the same patient cohort was slightly elevated (52\%) compared to the control group (41\%) [42]. It is important to note that the ELISA GST detection method used by Madeleine et al. yielded a much lower seroprevalence compared to other studies using the same technique. Similarly, serum from non-smoking-related lung cancer patients showed positivity for HPyV6 (76.9\%) and HPyV7 (65.2\%), which was comparable to the seroprevalence of these viruses in normal population age groups older than 50 years [43]. HPyV6 and 7 seropositivity data and results, including methodology, are summarized in Table 1. 
Table 1 Seroprevalence of HPyV6 and HPyV7 antibodies in serum using ELISA or Luminex platform

\begin{tabular}{|c|c|c|c|c|c|c|c|c|}
\hline \multirow[t]{2}{*}{ Source of the specimen } & \multirow[t]{2}{*}{ Age (y) } & \multirow{2}{*}{$\begin{array}{l}\text { Samples } \\
\mathrm{n}\end{array}$} & \multicolumn{2}{|c|}{ HPyV6 Positive n (\%) } & \multicolumn{2}{|c|}{ HPyV7 Positive n (\%) } & \multirow[t]{2}{*}{ Assay } & \multirow[t]{2}{*}{ Referenc } \\
\hline & & & $\overline{\text { VLP }}$ & GST & $\overline{\mathrm{VLP}}$ & GST & & \\
\hline \multirow{11}{*}{$\begin{array}{l}\text { 18-65 (y) Blood donors. } \\
<18 \text { or }>65(y) \\
\text { From discarded lab samples }\end{array}$} & $1-4$ & 48 & $18(37.5)$ & & $5(10.4)$ & & \multirow[t]{11}{*}{ ELISA } & \multirow[t]{11}{*}{ [39] } \\
\hline & $5-9$ & 69 & $40(57.9)$ & & $23(33.3)$ & & & \\
\hline & $10-14$ & 92 & $65(70.6)$ & & $41(44.6)$ & & & \\
\hline & $15-19$ & 89 & $55(61.8)$ & & $32(36)$ & & & \\
\hline & $20-29$ & 49 & $43(87.8)$ & & $22(44.9)$ & & & \\
\hline & $30-39$ & 73 & $49(67.1)$ & & $31(42.5)$ & & & \\
\hline & $40-49$ & 105 & $89(84.8)$ & & $62(59.1)$ & & & \\
\hline & $50-59$ & 95 & $78(82.1)$ & & $64(67.4)$ & & & \\
\hline & $60-69$ & 100 & $88(88)$ & & $68(68)$ & & & \\
\hline & $70-79$ & 52 & $46(88.5)$ & & $42(80.8)$ & & & \\
\hline & $\geq 80$ & 56 & $55(98.2)$ & & $48(85.7)$ & & & \\
\hline \multirow[t]{5}{*}{ Blood donors } & $20-29$ & 96 & $82(85.4)$ & $77(80.2)$ & $58(60.4)$ & $68(70.8)$ & \multirow[t]{5}{*}{ ELISA } & \multirow[t]{5}{*}[37]{} \\
\hline & $30-39$ & 129 & $114(88.4)$ & $111(86)$ & $92(71.3)$ & $106(82.2)$ & & \\
\hline & $40-49$ & 52 & $48(92.3)$ & $48(92.3)$ & $32(61.5)$ & $40(76.9)$ & & \\
\hline & $50-59$ & 24 & $22(91.7)$ & $21(87.5)$ & $16(66.7)$ & $19(79.2)$ & & \\
\hline & $>59$ & 5 & $4(80)$ & $4(80)$ & $3(60)$ & $4(80)$ & & \\
\hline \multirow[t]{14}{*}{ Serum obtained for routine lab tests } & $0-0.5$ & 31 & & $25(80.6)$ & & $18(58.1)$ & \multirow[t]{14}{*}{ Luminex platform } & \multirow[t]{14}{*}{ [40] } \\
\hline & $0.6-1.9$ & 63 & & $14(22.2)$ & & $12(19)$ & & \\
\hline & $2-3$ & 62 & & $21(33.9)$ & & $12(19.4)$ & & \\
\hline & $4-5$ & 58 & & $26(44.8)$ & & 19 (32.8) & & \\
\hline & $6-7$ & 58 & & $29(50)$ & & $21(36.2)$ & & \\
\hline & $8-9$ & 70 & & $44(62.9)$ & & $27(38.6)$ & & \\
\hline & $10-14$ & 55 & & $31(56.4)$ & & $21(38.2)$ & & \\
\hline & $15-19$ & 59 & & $38(64.4)$ & & $25(42.4)$ & & \\
\hline & $20-29$ & 59 & & $39(66.1)$ & & $30(50.8)$ & & \\
\hline & $30-39$ & 64 & & $41(64.1)$ & & $35(54.7)$ & & \\
\hline & $40-49$ & 54 & & $34(63)$ & & $33(61.1)$ & & \\
\hline & $50-59$ & 58 & & $46(79.3)$ & & $36(62.1)$ & & \\
\hline & $60-69$ & 54 & & $50(92.6)$ & & $45(83.3)$ & & \\
\hline & $>70$ & 54 & & $50(92.6)$ & & $46(85.2)$ & & \\
\hline \multirow[t]{5}{*}{ Blood donors } & $18-29$ & 208 & & $156(75.7)$ & & $117(56.8)$ & \multirow[t]{5}{*}{ Luminex platform } & \multirow[t]{5}{*}[38]{} \\
\hline & $30-39$ & 209 & & $175(84.5)$ & & $154(74.4)$ & & \\
\hline & $40-49$ & 208 & & $173(83.6)$ & & $155(74.9)$ & & \\
\hline & $50-59$ & 215 & & $184(85.6)$ & & $154(71.6)$ & & \\
\hline & $60-69$ & 210 & & $187(89.5)$ & & $169(80.9)$ & & \\
\hline Blood donors & & 95 & $66(69)$ & & $33(35)$ & & ELISA & {$[23]$} \\
\hline SCCs transplanted cases & & 110 & & $65(59)$ & & $57(51.8)$ & \multirow[t]{2}{*}{ ELISA and Luminex platform } & \multirow[t]{2}{*}[42]{} \\
\hline Non-SCCs transplanted cases & & 207 & & $137(66.2)$ & & $85(41)$ & & \\
\hline Lung cancer & & 511 & $393(76.9)$ & & $333(65.2)$ & & Luminex platform & {$[43]$} \\
\hline Controls & & 508 & $400(78.7)$ & & $334(65.8)$ & & & \\
\hline
\end{tabular}




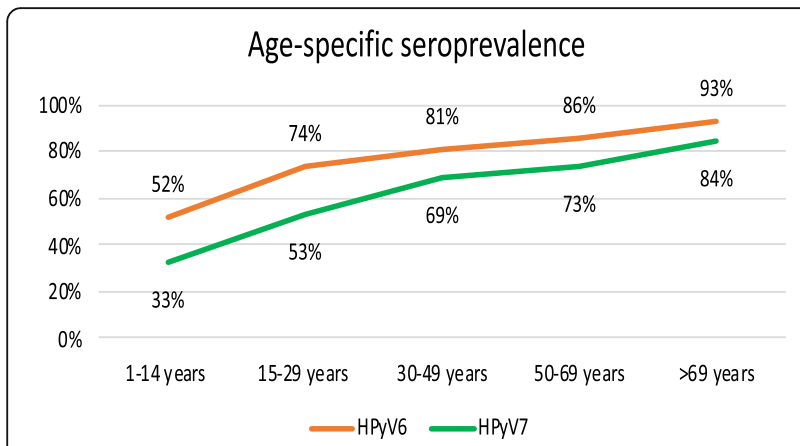

Fig. 1 Summarizing age-specific seroprevalence overall positivity of HPyV6 and HPyV7 using ELISA or Luminex platform-based methods to analyze antibodies against virus-like particles and/or glutathioneS-transferase consisting HPyV6 and 7 viral protein

In the past, studies on the seroprevalence of other human tumor viruses, e.g. Epstein-Barr virus or human papillomaviruses (HPV), have helped to indirectly indicate whether or not these viruses are involved in the etiopathogenesis of human cancers [44-48]. Moreover, the infection by small DNA tumor viruses at an early age, such as high-risk HPV, has been identified as a potential cause of human cancer decades after infection [47-49]. Also, HPyV6 and 7 antibodies are already detectable in the sera of healthy individuals at an early age Table 1 indicating that a substantial number of individuals - if not the majority - acquire both viruses already during their early lifetime, which might be a prerequisite for the onset of a possibly associated disease or cancer later in life.

\section{Prevalence of HPyV6 and HPyV7 DNA in non-neoplastic diseases}

A limited number of studies have screened for the prevalence of HPyV6- and HPyV7-DNA in nonneoplastic diseases, with very low prevalence across a variety of specimens Table 2. Both HPyVs were reported in Kimura's disease - a chronic inflammatory disorder associated with lymphadenopathy - with $4 / 5$ and $1 / 5$ samples found to be positive for HPyV6- and HPyV7DNA, respectively [50]. Only HPyV6-DNA was detected in lichen simplex chronicus (1/13 samples), Kikuchi disease, i.e. histiocytic necrotizing lymphadenitis (3/8 samples), dermatopathic lymph-adenitis (1/28 samples), and angiolymphoid hyperplasia with eosinophilia (ALHE) (4/ 5 samples) [24, 54, 55]. In addition, only one study showed the presence of HPyV6-DNA in lymphocytes of lymph nodes tissue from ALHE case by fluorescence in situ hybridization (FISH) [54].

Studies conducted on patients with cutaneous diseases have reported the presence of both HPyV6- and 7-DNA in tissue specimens. Three dyskeratotic dermatosis cases tissue revealed 2 positives for HPyV6 and 1 positive for
HPyV7, and in previously $12 \mathrm{HPV}$-induced warts tested showed that 3 positives for HPyV6 and 8 for HPyV7 [50, 53]. In addition, HPyV7-DNA was found in all three biopsies of pruritic patients, thus the diagnostic term HPyV 7-associated pruritic rash has been introduced in transplantation medicine $[51,52]$. The higher prevalence of both viruses in skin disease samples could be attributed to their high occurrence in the skin of healthy individuals. However, the viral load and prevalence of both viruses seem to increase in the skin of elderly people, in particular immunosuppressed individuals, which may lead to associated skin disorders [65].

The prevalence of HPyV6- and 7-DNA in nonneoplastic non-cutaneous diseases appears to be much lower compared to non-neoplastic skin diseases. Our group reported the presence of HPyV7-DNA in $(3 / 8$; $40 \%$ ) of non-malignant thymic hyperplasia [31]. Other studies detected HPyV6-DNA in $(12 / 226$; $5.3 \%)$ of tonsillitis tissue specimens Table 2 [56-58]. The detection rate of both viruses was found to be slightly higher in tissue specimens in contrast to body fluids specimens $[24,31,50-54,56-61,63,64]$. For instance, in cerebrospinal fluid, HPyV6-DNA was detected in $(1 / 14 ; 7.1 \%)$ samples from HIV patients with leukoencephalopathies and $(1 / 135 ; 0.7 \%)$ samples from patients with meningoencephalitis [61, 62]. In addition, $(5 / 91 ; 5.5 \%)$ bile fluid samples from acute gallstone cholangitis patients tested positive for HPyV6 [64]. In comparison, there was a low detection rate $(<2 \%)$ of both viruses in nasopharyngeal aspirates specimens collected from respiratory symptomatic patients $[59,60]$. Similarly, the presence of HPyV6 and 7 was uncommon $(<1 \%)$ in the feces obtained from patients with gastrointestinal illness for routine lab investigation [59]. Overall, the prevalence of HPyV6 and HPyV7 in formalin-fixed-paraffin-embedded (FFPE) and fresh frozen biopsies were elevated compared to liquid biopsy specimens, in which the prevalence of HPyV6 and HPyV7 was 1.1 and $0.2 \%$, respectively Table 2 .

\section{HPyV6 and HPyV7 DNA prevalence in primary cutaneous malignancies}

According to the World Health Organization, the incidence of skin tumors has increased over the past decades, approximately 8500 new cases of skin cancers are reported daily in the United States $[66,67]$. Up to date, the presence of the DNA of five HPyVs has been reported in the human skin: MCPyV, HPyV6, HPyV7, HPyV9, and trichodysplasia spinulosa-associated polyomavirus [40]. Of these, only MCPyV has been identified as a novel human tumor virus closely linked to the etiopathogenesis of the majority of MCCs. Since HPyV6 and 7 were isolated from the skin their possible contribution to the etiopathogenesis of skin cancers has been studied intensively [24-30,68]. Numerous studies, summarized 
Table 2 Prevalence of HPyV6 and HPyV7 in human non-neoplastic diseases

\begin{tabular}{|c|c|c|c|c|c|c|}
\hline Non-neoplastic disease & Specimen & $\begin{array}{l}\text { Samples } \\
\mathrm{n}\end{array}$ & Method & $\begin{array}{l}\text { HPyV6 } \\
\text { Positive n (\%) }\end{array}$ & $\begin{array}{l}\text { HPyV7 } \\
\text { Positive n (\%) }\end{array}$ & Reference \\
\hline \multicolumn{7}{|l|}{ Cutaneous diseases } \\
\hline Dyskeratosis and parakeratosis & FFPE & 3 & $\mathrm{PCR} / \mathrm{qPCR} / \mathrm{HC} / \mathrm{Seq}$. & $2(66.6)$ & $1(33.3)$ & {$[50]$} \\
\hline Lichen simplex chronicus & $\mathrm{FF}$ & 13 & $\mathrm{rt}-\mathrm{PCR}$ & $1(7.7)$ & ND & [24] \\
\hline Pruritic in Cardiac transplant recipient & FFPE & 1 & $\mathrm{IHC} / \mathrm{PCR}$ & NA & $1(100)$ & {$[51]$} \\
\hline Pruritic Rash (lung transplant) & FFPE & 2 & $\mathrm{HC} / \mathrm{PCR} / \mathrm{RCA} \mathrm{PCR} / \mathrm{rt}-\mathrm{PCR}$ & NA & $2(100)$ & [52] \\
\hline Viral warts & FFPE & 12 & $\mathrm{qPCR}$ & $3(25)$ & $8(66.7)$ & [53] \\
\hline $\begin{array}{l}\text { Angiolymphoid hyperplasia with eosinophilia } \\
\text { or Kimura disease } \mathrm{a}^{\mathrm{a}}\end{array}$ & $\mathrm{FF}$ & 1 & $\begin{array}{l}\text { Shotgun metagenomic/ } \\
\text { FISH }\end{array}$ & $1(100)$ & NA & [54] \\
\hline Angiolymphoid hyperplasia with eosinophilia & FFPE & 5 & $\mathrm{qPCR} / \mathrm{IHC}$ & $4(80)$ & 0 & {$[55]$} \\
\hline Kimura disease & FFPE & 5 & $\mathrm{qPCR} / \mathrm{IHC}$ & $4(80)$ & $1(20)$ & [55] \\
\hline Kikuchi disease & FFPE & 38 & qPCR & $3(8)$ & 0 & {$[55]$} \\
\hline Dermatopathic lymphadenitis & FFPE & 28 & qPCR & $1(4)$ & 0 & {$[55]$} \\
\hline \multicolumn{7}{|l|}{ Non-cutaneous diseases } \\
\hline Thymic hyperplasia & FFPE & 20 & $\mathrm{PCR} / \mathrm{IHC} / \mathrm{FISH}$ & NA & $8(40)$ & {$[31]$} \\
\hline Chronic tonsillitis \& tonsillar hypertrophy & $\mathrm{FF}$ & 78 & Luminex-assay & $6(7.7)$ & ND & [56] \\
\hline Chronic tonsillitis \& tonsillar hyperplasia & $\mathrm{FF}$ & 40 & qPCR & $1(2.5)$ & ND & {$[57]$} \\
\hline $\begin{array}{l}\text { Tonsillectomy (due to chronic tonsillitis, } \\
\text { peritonsillar abscess, or sleep apnea syndrome) }\end{array}$ & FF and FFPE & 108 & $\mathrm{qPCR}$ & $5(4.6)$ & $1(0.9)$ & {$[58]$} \\
\hline Patients with respiratory symptoms & NPA & 1232 & $\mathrm{rt}-\mathrm{PCR}$ & $2(0.16)$ & $3(0.24)$ & [59] \\
\hline Respiratory tract infections & NPA & 887 & $r t-P C R$ & $15(1.7)$ & ND & {$[60]$} \\
\hline HIV patients with leukoencephalopathies. & CSF & 14 & $N G S / P C R$ & $1(7.1)$ & NA & {$[61]$} \\
\hline Meningoencephalitis & CSF & 135 & qPCR & $1(0.74)$ & 0 & {$[62]$} \\
\hline $\begin{array}{l}\text { Immunocompromised patients scheduled } \\
\text { to receive transplants }\end{array}$ & $\begin{array}{l}\text { NPS, urine, } \\
\text { fecal, plasma }\end{array}$ & 32 & $\mathrm{rt}-\mathrm{PCR}$ & $3(9.4)$ & $1(3.1)$ & [63] \\
\hline Acute gallstone cholangitis & Bile fluids & 91 & $\mathrm{rt}-\mathrm{PCR}$ & $5(5.5)$ & NA & [64] \\
\hline Patients with gastrointestinal illness & Fecal & 185 & $\mathrm{rt}-\mathrm{PCR}$ & $1(0.5)$ & $1(0.5)$ & {$[59]$} \\
\hline
\end{tabular}

${ }^{\mathrm{a} A L H E}$ case with Kimura disease clinical syndromes

FF fresh frozen tissue, FFPE formalin-fixed paraffin-embedded, FISH fluorescence in situ hybridization, IHC immunohistochemistry, NA not applicable, ND not detected, NGS next-generation sequencing, NPA nasopharyngeal aspirates, NPS nasopharyngeal swab, $P C R$ polymerase chain reaction, $q P C R$ quantitative polymerase chain reaction, $r t-P C R$ real-time polymerase chain reaction, Seq Sanger sequencing

in Table 3, have assessed the prevalence of HPyV6- and 7-DNA in primary cutaneous malignancies, including epithelial, neuroendocrine, and lymphoid skin cancers.

One study reported the presence of HPyV6- and HPyV7-DNA (2/47; 4.3\%) in malignant melanoma (MM) specimens using rt-PCR [25]. In non-melanoma skin cancer tissues, both HPyV6- and 7-DNA have also been identified. Four studies have shown the presence of HPyV6-DNA in the most common human skin cancer, i.e. basal cell carcinoma (BCC) Table 3. The detection rate was between 2 to $21 \%$, and one study confirmed the detection of HPyV6 in BCC by FISH [25, 27, 29, 68]. HPyV7-DNA was identified in $4 \%$ of BCC cases by rtPCR in a single study [25]. Studies on squamous cell carcinoma (SCC), which is the second most common human cutaneous malignancy, revealed a prevalence between 3 to $38 \%$ for HPyV6 [25, 27-29, 68]. Other studies tested keratoacanthoma and trichoblastoma for
HPyV6-DNA, although no studies have tested trichoblastoma for HPyV7 [27, 68]. HPyV6- and 7-DNA were detected in $<2 \%$ of tissue biopsies from MCC and $<4 \%$ of actinic keratosis tissues [27, 29, 30, 53, 69]. To date, only one study has analyzed verrucous keratosis tissues, and $(3 / 4 ; 75 \%)$ specimens were positive for both viruses [53]. Another study by Schrama et al. detected HPyV6 in all tested 18 epithelial proliferation specimens (SCC and/or keratoacanthoma obtained from MM patients treated with the BRAF inhibitor vemurafenib) and HPyV7 in 17/18 specimens using rt-PCR combined with immunohistochemistry (IHC) using 6V32 and 6V12 antibodies targeting HPyV6 VP1 and have crossreactivity with HPyV7 [26]. It is of interest to mention that only very few studies report the usage of IHC to screen for HPyV6 and 7 protein expression, due to the lack of commercially available HPyV6- or 7-specific antibodies. In this respect, one may also consider the use of 
Table 3 Prevalence of HPyV6 and HPyV7 in primary cutaneous malignancies

\begin{tabular}{|c|c|c|c|c|c|c|}
\hline Cancer & Specimen types & Samples $\mathbf{n}$ & Method & HPyV6 Positive n (\%) & HPyV7 Positive n (\%) & Reference \\
\hline $\mathrm{MM}$ & FFPE & 47 & $\mathrm{rt}-\mathrm{PCR} / \mathrm{Seq}$ & $2(4.3)$ & $2(4.3)$ & {$[25]$} \\
\hline AK & FFPE & 31 & qPCR & $1(3)$ & ND & [27] \\
\hline AK & FFPE & 92 & Seq. & $4(4.3)$ & NA & [69] \\
\hline AK & FFPE & 2 & qPCR & ND & $1(50)$ & {$[53]$} \\
\hline VK & FFPE & 4 & qPCR & $3(75)$ & $3(75)$ & [53] \\
\hline $\mathrm{BCC}$ & FFPE & 18 & $\mathrm{qPCR}$ & $10(5.5)$ & ND & [29] \\
\hline $\mathrm{BCC}$ & FFPE & 41 & qPCR & $3(7)$ & ND & [27] \\
\hline $\mathrm{BCC}$ & FFPE & 50 & $\mathrm{rt}-\mathrm{PCR} / \mathrm{Seq}$ & $1(2)$ & $2(4)$ & {$[25]$} \\
\hline $\mathrm{BCC}$ & FFPE & 109 & PCR/Seq./FISH & $23(21.1)$ & NA & {$[68]$} \\
\hline SCC & FFPE & 8 & $\mathrm{qPCR}$ & $1(12)$ & ND & [27] \\
\hline SCC & FFPE & 21 & qPCR & $8(38)$ & ND & [29] \\
\hline SCC & FFPE & 52 & qPCR & $2(4)$ & ND & [27] \\
\hline SCC & FFPE & 86 & PCR/Seq./FISH & $8(9.3)$ & NA & {$[68]$} \\
\hline SCC & FFPE & 63 & $\mathrm{rt}-\mathrm{PCR} / \mathrm{Seq}$ & $2(3.2)$ & $1(1.6)$ & {$[25]$} \\
\hline SCC IN CLL cases who had BMT & FFPE & 3 & $\begin{array}{l}\text { Bead-based } \\
\text { multiplex PCR }\end{array}$ & $1(33.3)$ & ND & {$[28]$} \\
\hline SCC & FFPE & 11 & qPCR & $4(36.4)$ & $6(54.5)$ & {$[53]$} \\
\hline SCC & FFPE & 17 (6 patients) & rt-PCR/IHC & $17(100)$ & $17(100)$ & [26] \\
\hline KA & FFPE & 42 & qPCR & $2(5)$ & ND & [27] \\
\hline KA & FFPE & 59 & $\mathrm{PCR} / \mathrm{Seq} / \mathrm{FISH}$ & $25(42.3)$ & NA & [68] \\
\hline TB & FFPE & 45 & PCR/Seq & $10(22.2)$ & NA & {$[68]$} \\
\hline MCC & FFPE & 20 & qPCR & $2(10)$ & ND & [29] \\
\hline MCC & FFPE & 28 & $\mathrm{rt}-\mathrm{PCR}$ & $1(3.5)$ & $1(3.5)$ & [30] \\
\hline CTCLs & FFPE & 116 & $\mathrm{rt}-\mathrm{PCR}$ & $6(5.20)$ & $1(0.90)$ & [70] \\
\hline CTCLs & $\mathrm{FF}$ & 71 & rt-PCR & $13(18.3)$ & ND & [24] \\
\hline CTCLs & FF and FFPE & 35 & rt-PCR & $7(20)$ & $3(8.6)$ & [71] \\
\hline Total & & 1072 & & 157/1072 (14.6) & 37/681 (5.4) & \\
\hline
\end{tabular}

AK actinic keratosis, BCC basal cell carcinoma, BMT bone marrow transplantation, CLL chronic lymphocytic leukemia, CTCLs cutaneous T-cell lymphomas, FFPE formalin-fixed paraffin-embedded, FISH fluorescence in situ hybridization, IHC immunohistochemistry, FF fresh frozen tissue, KA keratoacanthoma, MCC Merkel cell carcinoma, $M M$ malignant melanoma, $N A$ not applicable, $N D$ not detected, $P C R$ polymerase chain reaction, $q P C R$ quantitative polymerase chain reaction, $r t-P C R$ real-time polymerase chain reaction, SCC squamous cell carcinoma, Seq Sanger sequencing, TB trichoblastoma, $V K$ verrucous keratosis

the commonly PAb416 antibody used in routine laboratories originally directed against the LTAg of SV40. PAb416 antibody which detects conserved epitope region of diverse HPyVs including HPyV6 and 7 but not detecting $\mathrm{MCPyV}$ which there is a commercial antibody (CM2B4) available to detect its LTAg [72, 73].

Additionally, primary cutaneous lymphomas have been tested for the presence of HPyV6- and 7-DNA: cutaneous T-cell lymphoma (CTCL) patients, and all three studies showed that CTCLs were positive (5.20 to 20\%) for HPyV6- and (0.90 to 8.6\%) for HPyV7-DNA, while no cutaneous B-cell lymphoma was positive for either virus $[24,70,71]$. Overall, results showed that the occurrence of HPyV6-DNA in CTCL was more frequent than HPyV7-DNA Table 3.

It is remarkable that HPyV6-DNA is far more often detected than HPyV7-DNA in human neoplastic skin diseases
(Fig. 2), which may indicate a role for HPyV6 in the etiopathogenesis of these cancers. However, the reported copy loads of HPyV6- and 7-DNA in diverse skin cancers do not clearly support this hypothesis. Studies reported a generally low viral load of HPyV6- and 7-DNA-positive skin cancers which does not reflect the situation of high viral load of MCPyV in MCC [25, 27, 29, 53, 74]. Nevertheless, viral load copies of HPyV6 per cell range (0.000140.14) and MCPyV (0.0016-0.36) were almost in the same range in non-MCC tumors such as SCC, BCC, and MM, while HPyV7 copy numbers (0.000079-0.0094) were much lower. Moreover, specimens from healthy skin specimens showed the same range of HPyV6-DNA and MCPyV-DNA viral load as non-MCC samples [25, 27, 29, 53]. Notably, HPyV7-DNA was more often detectable than HPyV6-DNA in non-cutaneous cancers, while HPyV6-DNA was identified more often in skin malignancies Tables 2 and 3. 

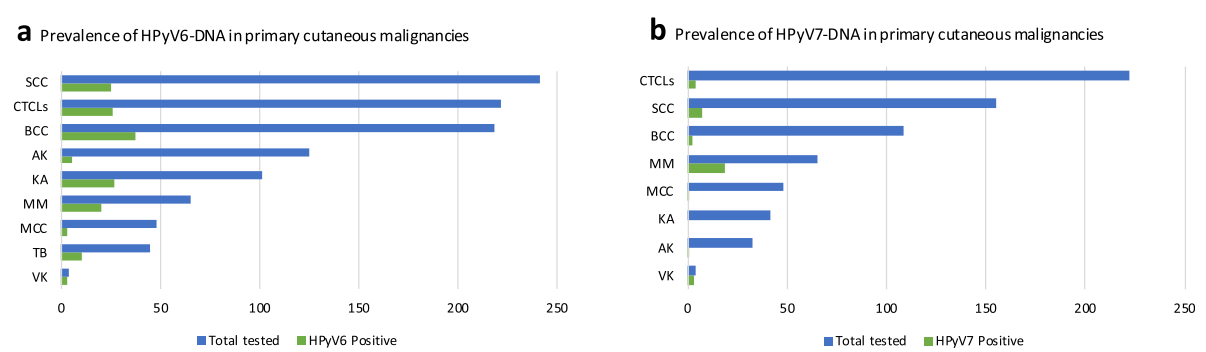

Fig. 2 Representing a summary of the prevalence of HPyV6-DNA (a) and HPyV7-DNA (b) in tissues of cutaneous malignancies. AK, actinic keratosis; BCC, basal cell carcinoma; CTCLs, cutaneous T-cell lymphomas; KA, keratoacanthoma; MCC, Merkel cell carcinoma; MM, malignant melanoma; SCC, squamous cell carcinoma; TB, trichoblastoma; VK, verrucous keratosis

\section{HPyV6 and HPyV7 in non-cutaneous malignancies}

The prevalence of HPyV6 and 7 have also been studied in a variety of non-cutaneous malignancies summarized in Table 4. In tissue specimens, HPyV7- but not HPyV6DNA was frequently (62\%) found in thymic epithelial tumors [31]. In contrast, HPyV6-DNA was more prevalent (5.4\%) in tonsillar SCC $[57,58]$.

In body fluids specimens, Chan et al. investigated the presence of HPyVs in the bile fluid of patients with a variety of hepatobiliary malignancies [64]. HPyV6 but not $\mathrm{HPyV} 7$ was detected in 27.6, 10.7, 16.7, and $20 \%$ of bile specimens from cholangiocarcinoma (CCA), hepatocellular carcinoma, pancreatic carcinoma, and gallbladder carcinoma patients, respectively [64]. We recently identified the presence of HPyV6- and 7-DNA in cholangiocarcinoma cases at the single-cell level by diverse molecular biology techniques for the detection of viral DNA, mRNA, and protein expression [77]. We found that $\mathrm{HPyV} 7$ was more prevalent than HPyV6 and indeed the presence of these viruses was not restricted to CCA tissues but also found in adjacent microscopically nonneoplastic hepatocytes [77].

Overall, among patients with different non-cutaneous cancers, HPyV7-DNA was more frequently detected than HPyV6-DNA in tissues. Yet, it remains unclear if and how HPyV7 might contribute to the tumorigenesis of these thymic epithelial tumors or cholangiocarcinomas, or that it rather is present in the context of viral latency.

\section{Latency and tropism}

The frequent prevalence of HPyV6- and 7-DNA in nonneoplastic tissues along with their high seropositivity indicates that these viruses remain in long-term latency in humans. Therefore, it is important to unmask the host cells facilitating this long-term latency in healthy individuals to understand the host cell-type specific encoded proteins needed for viral entrance, replication, and transcription.

So far, the underlying mechanisms of tissue tropism or the possible latency of HPyV6 and 7 are still unknown. Other HPyVs have been reported to remain in latency within the epithelium of the proximal tubule of the kidney (BKPyV) while JCPyV is found in the brain [3]. In other studies, BKPyV and JCPyV were suggested to be found latent in lymphoid tissues and lymphocytes [78]. Since the seroprevalence of HPyV6 and 7 is high in the general population, it is difficult to ultimately determine the latency compartment of these two HPyVs based on the currently available literature. However, keratinocytes have been identified to be the potential primary target of HPyV7 infection and replication [50]. In addition, since HPyV 6 and 7 have been detected in BCC, further

Table 4 Prevalence of HPyV6 and HPyV7 in non-cutaneous other human malignancies

\begin{tabular}{|c|c|c|c|c|c|c|}
\hline Tumor & Specimen & Samples $\mathbf{n}$ & Method & HPyV6 Positive n (\%) & HPyV7 Positive n (\%) & Reference \\
\hline $\mathrm{BC}$ & $\mathrm{FF}$ & 54 & $\mathrm{rt}-\mathrm{PCR}$ & $1(2)$ & $1(2)$ & [75] \\
\hline LSCC & $\mathrm{FF}$ & 7 & Luminex platform (Multiplex PCR) & $1(14.3)$ & ND & [76] \\
\hline TETs & FFPE & 37 & $\mathrm{FISH} / \mathrm{PCR} / \mathrm{Seq} / \mathrm{IHC}$ & ND & $23(62.2)$ & [31] \\
\hline TSCC & FF & 38 & $q P C R$ & $2(5.3)$ & $1(2.6)$ & [57] \\
\hline TC & FF and FFPE & 112 & qPCR & $6(5.4)$ & $2(1.8)$ & [58] \\
\hline CCA & FFPE & 42 & PCR/FISH/RISH/IHC & $4(9.5)$ & $19(45.2)$ & [77] \\
\hline
\end{tabular}

$B C$ breast cancer, CCA cholangiocarcinoma, FFPE formalin-fixed paraffin-embedded, FF Freshly frozen tissue, FISH fluorescence in situ hybridization, $L S C C$ laryngeal squamous cell carcinoma, ND not detected, $P C R$ polymerase chain reaction, $Q P C R$ quantitative polymerase chain reaction, rt- $P C R$ real-time polymerase chain reaction, RISH RNA fluorescence in situ hybridization, Seq Sanger sequencing, TC tonsillar carcinoma, TETs thymic epithelial tumors, TSCC tonsillar squamous cell carcinoma 
studies are needed to investigate whether they act similar to HPV by infecting the basal epithelial cells through lesions in the epidermis and undergo episomal replication in the parabasal layers $[25,27,29,68,79]$.

\section{Direct versus indirect HPyVs-related carcinogenesis}

The potential contribution of oncogenic viruses is either direct and/or indirect in the carcinogenesis of virusassociated tumors $[80,81]$. MCPyV is the only HPyV found to be clonally integrated into the genome of human cancer, namely MCC. Next to its clonal integration, the MCPyV genome carries tumor-specific mutations within the large tumor antigen (LTAg) introducing stop codons and thus abrogating the helicase expression and rendering MCPyV replication-deficient $[15,17]$. In direct carcinogenesis, one would expect a high expression of viral proteins in every tumor cell, which indeed is seen for the MCPyV-LTAg protein in MCPyV positive MCC $[15,17,82]$. In particular, the binding of truncated LTAg to the retinoblastoma protein-binding (RB) maintains the replication of MCPyV-positive MCC cells [3, 26, 83]. During the preparation of this review it occurred, that only a few studies report the protein expression of HPyV6 and 7 in neoplastic cells, possibly indicating such a direct tumorigenic role as shown for MCPyV and MCC. However, HPyV6- and 7-LTAg expression are not found in all tumor cells in the above mentioned possibly HPyV6 and 7-associated human cancers. Thus, it seems unlikely that both HPyVs play an important direct contribution to human tumorigenesis [26, 31, 77].

Human tumor viruses also can induce neoplasms by indirect mechanisms via the interaction between viral antigens, environmental factors, and other modifications to the host genome [80]. Inflammatory reactions due to the immune response to viral infection exposure can become eradicated and induce acute inflammation which may also result in chronic inflammation [84, 85]. Reactive oxygen radicals can be produced years later following chronic inflammation and trigger modifications in the host nucleic acids and then inducing transformation as it is known for hepatitis $B$ and $C$ viruses [84, 86]. For instance, the hepatitis $C$ virus is not detected in the cancer cells that may develop after many years of infection but are found in the adjacent lesions to the hepatocellular carcinoma [87-90]. The infection by the virus alone is not sufficient to develop a tumor, and persistent viral infection precedes possibly many years before a cancer develops by an indirect mechanism such as chronic inflammation. The recent finding of HPyV6 and 7 in hepato- and cholangiocellular tissues possibly indicates such a physiopathologic mechanism of chronic inflammation-related indirect carcinogenesis also for HPyV6 and 7 [77]. However, more studies are needed to further elucidate and establish chronic inflammation-related indirect carcinogenesis for HPyV6 and 7.

Besides the direct and indirect HPyVs-related carcinogenesis, the "hit and run" hypothesis has been proposed to explain a possible role of viral agents to mediate cellular transformation [91]. The "hit and run" concept was proposed by Skinner in 1976 as a model where the virus is required to initiate the tumorigenesis process by leading to mutations, which maintain the tumorigenesis resulting in tumor with loss of the viral genes in the later stages [91]. Few studies have suggested the "hit and run" mechanism to mediate transformation by BKPyV, JCPyV, and MCPyV [92-96]. However, this hypothesis remains speculative until further evidence for "hit and run" for - HPyV associated diseases is established.

In addition, HPyVs may contribute to human tumorigenesis together with other oncogenic viruses assuming, that two or maybe more different viruses potentially infect the same cells and interact with each other in the etiopathogenesis of human cancers [97-100]. Primary evidence for interplay and helper functions of viruses had been established since long, especially for adenoviruses and herpesviruses [101, 102]. Of interest, Heilbronn et al. reported the finding that cytomegalovirus (CMV) infection can trigger JCPyV-DNA replication in cultured human fibroblasts [103]. Indirect potential evidence for possible interplay and helper functions is currently restricted to observational findings: BKPyV has been found to be associated with the induction of cervical intraepithelial neoplasias, particularly in immunosuppressed patients $[104,105]$. Although these findings might point to an interaction of certain high-risk HPV types with BKPyV, they are by far no causal proof that BKPyV contributes to the HPV-related etiopathogenesis of cervical cancer. Coinfection with different human viruses has been also reported in oropharyngeal and oral cavity cancers [100]. Although there are yet no functional data available concerning possible interplay and helper functions of HPyVs with other viruses in human cancers, it might be interesting to study this for HPyV6 and 7.

\section{Further studies to elucidate the role of HPyV6 and 7 in etiopathogenesis of human cancers}

The HPyV6 and 7 contributions to human tumorigenesis are not yet elucidated. Therefore, several important questions regarding the pathogenesis of both viruses need to be addressed. For example, how to confirm the interaction of HPyV6 and HPyV7 in the inactivation of $\mathrm{p} 53$ and retinoblastoma protein $(\mathrm{pRb})$, or in the transformation function. Rozenblatt-Rosen et al. namely proposed this mechanism in which HPyV6 and 7 both LTAg and sTAg proteins to bind p53 and inactivate it leading to tumorigenesis [32]. MCPyV is the only known $\mathrm{HPyV}$ that is found to be clonally integrated into MCC 
cases, in particular, the binding of truncated LTAg to the $\mathrm{pRb}$ was found to maintain the growth of MCC in MCPyV-positive cell lines [3, 83, 106]. Furthermore, SV40, which is a non-HPyV, was reported to bind p53 and $\mathrm{Rb}$ and inactivate their function [107-109]. In addition, one study has shown that HPyV6 sTAg is capable to inactivate the tumor suppressor protein phosphatase 2A (PP2A) that results in hyperphosphorylation of the MEK-ERK pathway and leads to abnormal proliferation $[110,111]$.

The presence of HPyV6- and 7-DNA and their association with human malignancies have commonly been tested by PCR and qPCR. However, the conclusions that can be drawn from these studies restricting their level of evidence to the proof of viral nucleic acids in homogenized tissue extracts are unfortunately very limited. The meaning of the presence of viral nucleic acids must remain inconclusive because these findings cannot be interpreted on the single-cell level in the histomorphological context of the specific disease. In addition, only limited reliable data are available on the viral protein expression, because the detection of antibodies by IHC in FFPE tissues are lacking. A possible screening approach might start with the use of the PAb416 antibody followed by specific HPyV6 and 7 PCR. In addition, studies definitely are needed in order to investigate next to the presence of HPyV6-DNA and 7-DNA, if these viruses are integrated into the tumor genome and possibly carry tumor-specific mutations within the viral helicase of LTAg in analogy to MCPyV $[15,17]$. This will e.g. also help to understand the role of HPyV6 and 7 in skin carcinogenesis as a possible co-factor of UV-radiation as it is discussed for HPV5 and 8 association skin carcinogenesis $[49,112]$.

\section{Conclusion}

In this review, we aimed to comprehensively analyze the literature for a possible role of the two closely related HPyV6 and 7 in human diseases and cancers. The seropositivity of HPyV6 was found to be higher than HPyV7 and both increased with age. The etiopathogenetical contribution of these viruses to human cancers remains unclear. Studies revealed that low HPyV6 and HPyV7 prevalence in non-neoplastic tumors resembled those in malignancies. Interestingly, HPyV6 prevalence was higher in skin malignancies than that of HPyV7. In contrast, HPyV7 was more frequently detected in noncutaneous malignancies compared to HPyV6.

Based on sero- and tissue-prevalence HPyV6 and 7 remain important putative candidates for contributing to the etiopathogenesis of human disease, including skin cancers. There is an urgent need to further define their presence within cutaneous lesions e.g., keratoacanthoma, squamous cell carcinoma, and basal cell carcinoma, and to apply additional molecular techniques to unravel the molecular basis of virus-host interactions and assess a possible role of viral integration or mutation of the LTAg in skin cancer development. The same applies for HPyV7-associated tumors e.g., cholangiocellular carcinomas or thymomas. Further studies are needed to understand the contribution of HPyV6 and HPyV7 to human cancers.

\section{Abbreviations \\ HPyVs: Human polyomaviruses; HPyV6: Human polyomavirus 6: HPyV7: Human polyomavirus 7; PyV's: Polyomaviruses; MCPyV: Merkel cell polyomavirus; MCC: Merkel cell carcinoma; VP1: Viral protein 1; VLP: Virus-like particles; ELISA: Enzyme-linked immunosorbent assays; GST: Glutathione S- transferase; HPV: Human papillomavirus; ALHE: Angiolymphoid hyperplasia with eosinophilia; FISH: Fluorescence in situ hybridization; FFPE: Formalin- fixed-paraffin-embedded; MM: Malignant melanoma; BCC: Basal cell carcinoma; SCC: Squamous cell carcinoma; IHC: Immunohistochemistry; CTCL: Cutaneous T-cell lymphomas; CCA: Cholangiocarcinoma; LTAg: Large tumor antigen}

\section{Acknowledgments \\ None to declare.}

\section{Authors' contributions}

FK and $\mathrm{AzH}$ conceived and designed the study. FK, GM, and DL searched the literature, extract and analyzed the data. FK and AzH wrote the manuscript. AK, WW, RA, EJS were contributed to writing specific parts of the manuscript. $\mathrm{AzH}$ is the principal investigator and set up and supervised this review. All the authors read and approved this manuscript for publication.

\section{Funding \\ None to declare.}

Availability of data and materials

Not applicable.

\section{Declarations}

Ethics approval and consent to participate Not applicable.

Consent for publication

Not applicable.

\section{Competing interests}

The authors declare that they have no competing interests.

\section{Author details}

${ }^{1}$ Department of Pathology, GROW-School for Oncology \& Developmental Biology, Maastricht University Medical Centre+, Maastricht, the Netherlands. ${ }^{2}$ Department of Laboratory Medicine, Faculty of Applied Medical Sciences, Albaha University, Albaha, Saudi Arabia. ${ }^{3}$ Department of Medical Laboratories Technology, Faculty of Applied Medical Sciences, Jazan University, Jazan, Saudi Arabia. ${ }^{4}$ Department of Hematology, The Affiliated Hospital of Southwest Medical University, Luzhou, China. ${ }^{5}$ Department of Internal Medicine IV, RWTH Aachen University Hospital, Aachen, Germany.

Received: 9 March 2021 Accepted: 4 May 2021

Published online: 17 May 2021

\section{References}

1. Johne R, Buck CB, Allander T, Atwood WJ, Garcea RL, Imperiale MJ, et al. Taxonomical developments in the family Polyomaviridae. Arch Virol. 2011; 156(9):1627-34. https://doi.org/10.1007/s00705-011-1008-x.

2. Johne R, Müller H. Polyomaviruses of birds: etiologic agents of inflammatory diseases in a tumor virus family. J Virol. 2007:81(21):11554-9. https://doi. org/10.1128/JVl.01178-07. 
3. DeCaprio JA, Garcea RL. A cornucopia of human polyomaviruses. Nat Rev Microbiol. 2013;11(4):264-76. https://doi.org/10.1038/nrmicro2992.

4. Small JA, Khoury G, Jay G, Howley PM, Scangos GA. Early regions of JC virus and BK virus induce distinct and tissue-specific tumors in transgenic mice. Proc Natl Acad Sci U S A. 1986;83(21):8288-92. https://doi.org/10.1073/pnas.83.21.8288.

5. Dalrymple SA, Beemon KL. BK virus T antigens induce kidney carcinomas and thymoproliferative disorders in transgenic mice. J Virol. 1990;64(3):118291. https://doi.org/10.1128/JVI.64.3.1182-1191.1990.

6. Ramqvist T, Dalianis T. Murine polyomavirus tumour specific transplantation antigens and viral persistence in relation to the immune response, and tumour development. Semin Cancer Biol. 2009;19(4):236-43. https://doi. org/10.1016/j.semcancer.2009.02.001.

7. Zur Hausen H. Novel human polyomaviruses--re-emergence of a well known virus family as possible human carcinogens. Int J Cancer. 2008; 123(2):247-50. https://doi.org/10.1002/ijc.23620.

8. Moens U, Prezioso C, Pietropaolo V. Genetic Diversity of the Noncoding Control Region of the Novel Human Polyomaviruses. Viruses. 2020;12(12): 1406. https://doi.org/10.3390/v12121406.

9. ICTV-Report-pConsortium. Report on the taxonomy of the Polyomaviridae. Virus Taxonomy: 2018b Release. International Committee on Taxonomy of Viruses. 2019.

10. Gedvilaite A, Tryland M, Ulrich RG, Schneider J, Kurmauskaite V, Moens U, et al. Novel polyomaviruses in shrews (Soricidae) with close similarity to human polyomavirus 12. J Gen Virol. 2017;98(12):3060-7. https://doi.org/10.1 099/jgv.0.000948.

11. Fahsbender E, Altan E, Estrada M, Seguin MA, Young P, Leutenegger CM, et al. Lyon-IARC Polyomavirus DNA in Feces of Diarrheic Cats. Microbiol Resour Announc. 2019;8(29):e00550-19. https://doi.org/10.1128/MRA. 00550-19.

12. Ondov BD, Starrett GJ, Sappington A, Kostic A, Koren S, Buck CB, et al. Mash screen: high-throughput sequence containment estimation for genome discovery. Genome Biol. 2019;20(1):232. https://doi.org/10.1186/s13059-019-1 $841-\mathrm{x}$.

13. Buck CB, Van Doorslaer K, Peretti A, Geoghegan EM, Tisza MJ, An P, et al. The ancient evolutionary history of polyomaviruses. PLoS Pathog. 2016;12(4): e1005574. https://doi.org/10.1371/journal.ppat.1005574

14. Torres C. Evolution and molecular epidemiology of polyomaviruses. Infect Genet Evol. 2020;79:104150. https://doi.org/10.1016/j.meegid.2019.104150.

15. Feng $H$, Shuda M, Chang Y, Moore PS. Clonal integration of a polyomavirus in human Merkel cell carcinoma. Science. 2008:319(5866):1096-100.

16. Kassem A, Schopflin A, Diaz C, Weyers W, Stickeler E, Werner M, et al. Frequent detection of Merkel cell polyomavirus in human Merkel cell carcinomas and identification of a unique deletion in the VP1 gene. Cancer Res. 2008;68(13):5009-13. https://doi.org/10.1158/0008-5472.CAN-08-0949.

17. Shuda M, Feng H, Kwun HJ, Rosen ST, Gjoerup O, Moore PS, et al. T antigen mutations are a human tumor-specific signature for Merkel cell polyomavirus. Proc Natl Acad Sci U S A. 2008;105(42):16272-7. https://doi. org/10.1073/pnas.0806526105.

18. Bouvard V, Baan RA, Grosse Y, Lauby-Secretan B, El Ghissassi F, BenbrahimTallaa L, et al. Carcinogenicity of malaria and of some polyomaviruses. Lancet Oncol. 2012;13(4):339-40. https://doi.org/10.1016/S1470-2045(12)70125-0.

19. Pantulu ND, Pallasch CP, Kurz AK, Kassem A, Frenzel L, Sodenkamp S, et al. Detection of a novel truncating Merkel cell polyomavirus large T antigen deletion in chronic lymphocytic leukemia cells. Blood. 2010;116(24):5280-4. https://doi.org/10.1182/blood-2010-02-269829.

20. Toracchio S, Foyle A, Sroller V, Reed JA, Wu J, Kozinetz CA, et al. Lymphotropism of Merkel cell polyomavirus infection, Nova Scotia, Canada Emerg Infect Dis. 2010;16(11):1702-9. https://doi.org/10.3201/eid1611.100628.

21. Teman CJ, Tripp SR, Perkins SL, Duncavage EJ. Merkel cell polyomavirus (MCPyV) in chronic lymphocytic leukemia/small lymphocytic lymphoma. Leuk Res. 2011;35(5):689-92. https://doi.org/10.1016/j.leukres.2011.01.032

22. Imajoh M, Hashida Y, Taniguchi A, Kamioka M, Daibata M. Novel human polyomaviruses, Merkel cell polyomavirus and human polyomavirus 9, in Japanese chronic lymphocytic leukemia cases. J Hematol Oncol. 2012;5(1): 25. https://doi.org/10.1186/1756-8722-5-25.

23. Schowalter RM, Pastrana DV, Pumphrey KA, Moyer AL, Buck CB. Merkel cell polyomavirus and two previously unknown polyomaviruses are chronically shed from human skin. Cell Host Microbe. 2010;7(6):509-15. https://doi. org/10.1016/j.chom.2010.05.006.

24. Fava P, Merlino C, Novelli M, Ponti R, Galliano I, Montanari P, et al. HPyV6, HPyV7 and TSPyV DNA sequences detection in skin disease patients and healthy subjects. J Eur Acad Dermatol Venereol. 2016;30(4):624-7. https:// doi.org/10.1111/jdv.13094.

25. Imajoh M, Hashida Y, Nakajima H, Sano S, Daibata M. Prevalence and viral DNA loads of three novel human polyomaviruses in skin cancers from Japanese patients. J Dermatol. 2013;40(8):657-60. https://doi.org/1 $0.1111 / 1346-8138.12180$.

26. Schrama D, Groesser L, Ugurel S, Hafner C, Pastrana DV, Buck CB, et al. Presence of human polyomavirus 6 in mutation-specific BRAF inhibitorinduced epithelial proliferations. JAMA Dermatol. 2014;150(11):1180-6. https://doi.org/10.1001/jamadermatol.2014.1116.

27. Scola N, Wieland U, Silling S, Altmeyer P, Stucker M, Kreuter A. Prevalence of human polyomaviruses in common and rare types of non-Merkel cell carcinoma skin cancer. Br J Dermatol. 2012;167(6):1315-20. https://doi.org/1 0.1111/j.1365-2133.2012.11141.x.

28. Hampras SS, Locke FL, Chavez JC, Patel NS, Giuliano AR, Miller K, et al. Prevalence of cutaneous viral infections in incident cutaneous squamous cell carcinoma detected among chronic lymphocytic leukemia and hematopoietic stem cell transplant patients. Leuk Lymphoma. 2018;59(4): 911-7. https://doi.org/10.1080/10428194.2017.1342822.

29. Schrama D, Buck CB, Houben R, Becker JC. No evidence for association of HPyV6 or HPyV7 with different skin cancers. J Invest Dermatol. 2012;132(1): 239-41. https://doi.org/10.1038/jid.2011.261.

30. Duncavage EJ, Pfeifer JD. Human polyomaviruses 6 and 7 are not detectable in Merkel cell polyomavirus-negative Merkel cell carcinoma. J Cutan Pathol. 2011;38(10):790-6. https://doi.org/10.1111/j.1600-0560.2011.01 765.x.

31. Rennspiess D, Pujari S, Keijzers M, Abdul-Hamid MA, Hochstenbag M, Dingemans AM, et al. Detection of human polyomavirus 7 in human thymic epithelial tumors. J Thorac Oncol. 2015;10(2):360-6. https://doi.org/10.1097/ JTO.0000000000000390.

32. Rozenblatt-Rosen O, Deo RC, Padi M, Adelmant G, Calderwood MA, Rolland $T$, et al. Interpreting cancer genomes using systematic host network perturbations by tumour virus proteins. Nature. 2012;487(7408):491-5. https://doi.org/10.1038/nature11288.

33. Prado JCM, Monezi TA, Amorim AT, Lino V, Paladino A, Boccardo E. Human polyomaviruses and cancer: an overview. Clinics. 2018;73(suppl 1):e558s. https://doi.org/10.6061/clinics/2018/e558s.

34. Delbue S, Comar M, Ferrante P. Review on the relationship between human polyomaviruses-associated tumors and host immune system. Clin Dev Immunol. 2012;2012:542092. https://doi.org/10.1155/2012/542092.

35. White MK, Khalili K. Polyomaviruses and human cancer: molecular mechanisms underlying patterns of tumorigenesis. Virology. 2004;324(1):116. https://doi.org/10.1016/j.virol.2004.03.025.

36. Moens U, Rasheed K, Abdulsalam I, Sveinbjornsson B. The role of Merkel cell polyomavirus and other human polyomaviruses in emerging hallmarks of cancer. Viruses. 2015;7(4):1871-901. https://doi.org/10.3390/v7041871.

37. Sroller V, Hamsikova E, Ludvikova V, Musil J, Nemeckova S, Salakova M. Seroprevalence rates of HPyV6, HPyV7, TSPyV, HPyV9, MWPyV and KIPyV polyomaviruses among the healthy blood donors. J Med Virol. 2016;88(7): 1254-61. https://doi.org/10.1002/jmv.24440.

38. Kamminga S, van der Meijden E, Feltkamp MCW, Zaaijer HL. Seroprevalence of fourteen human polyomaviruses determined in blood donors. PLoS One. 2018;13(10):e0206273. https://doi.org/10.1371/journal.pone.0206273.

39. Nicol JT, Robinot R, Carpentier A, Carandina G, Mazzoni E, Tognon M, et al. Age-specific seroprevalences of merkel cell polyomavirus, human polyomaviruses 6, 7, and 9, and trichodysplasia spinulosa-associated polyomavirus. Clin Vaccine Immunol. 2013;20(3):363-8. https://doi.org/1 $0.1128 /$ CVI.00438-12

40. van der Meijden E, Bialasiewicz S, Rockett RJ, Tozer SJ, Sloots TP, Feltkamp MC. Different serologic behavior of MCPyV, TSPyV, HPyV6, HPyV7 and HPyV9 polyomaviruses found on the skin. PLoS One. 2013;8(11):e81078. https://doi. org/10.1371/journal.pone.0081078.

41. Kamminga S, van der Meijden E, Wunderink HF, Touze A, Zaaijer HL, Feltkamp MCW. Development and Evaluation of a Broad Bead-Based Multiplex Immunoassay To Measure IgG Seroreactivity against Human Polyomaviruses. J Clin Microbiol. 2018;56(4):e01566-17. https://doi.org/1 0.1128/JCM.01566-17.

42. Madeleine MM, Carter JJ, Johnson LG, Wipf GC, Davis C, Berg D, et al. Risk of squamous cell skin cancer after organ transplant associated with antibodies to cutaneous papillomaviruses, polyomaviruses, and TMC6/8 (EVER1/2) variants. Cancer Med. 2014;3(5):1440-7. https://doi.org/10.1002/cam4.280. 
43. Malhotra J, Waterboer T, Pawlita M, Michel A, Cai Q, Zheng W, et al. Serum biomarkers of polyomavirus infection and risk of lung cancer in never smokers. Br J Cancer. 2016;1 15(9):1131-9. https://doi.org/10.1038/bjc.2016.285.

44. Vaillant V, Reiter A, Zimmermann M, Wagner HJ. Seroepidemiological analysis and literature review of the prevalence of Epstein-Barr virus and herpesvirus infections in pediatric cases with non-Hodgkin lymphoma in Central Europe. Pediatr Blood Cancer. 2019;66(7):e27752. https://doi.org/10.1 002/pbc.27752.

45. Orem J, Sandin S, Mbidde E, Mangen FW, Middeldorp J, Weiderpass E. Epstein-Barr virus viral load and serology in childhood non-Hodgkin's lymphoma and chronic inflammatory conditions in Uganda: implications for disease risk and characteristics. J Med Virol. 2014;86(10):1796-803. https://doi.org/10.1002/jmv.23988.

46. Ji MF, Wang DK, Yu YL, Guo YQ, Liang JS, Cheng WM, et al. Sustained elevation of Epstein-Barr virus antibody levels preceding clinical onset of nasopharyngeal carcinoma. Br J Cancer. 2007;96(4):623-30. https://doi.org/1 $0.1038 /$ sj.bjc.6603609.

47. Shah KV, Viscidi RP, Alberg AJ, Helzlsouer KJ, Comstock GW. Antibodies to human papillomavirus 16 and subsequent in situ or invasive cancer of the cervix. Cancer Epidemiol Biomark Prev. 1997;6(4):233-7.

48. Lehtinen M, Dillner J, Knekt $P$, Luostarinen $T$, Aromaa A, Kirnbauer $R$, et al. Serologically diagnosed infection with human papillomavirus type 16 and risk for subsequent development of cervical carcinoma: nested case-control study. BMJ. 1996;312(7030):537-9. https://doi.org/10.1136/ bmj.312.7030.537.

49. Karagas MR, Nelson HH, Sehr P, Waterboer T, Stukel TA, Andrew A, et al. Human papillomavirus infection and incidence of squamous cell and basal cell carcinomas of the skin. J Natl Cancer Inst. 2006;98(6):389-95. https://doi. org/10.1093/jnci/djj092.

50. Nguyen KD, Lee EE, Yue Y, Stork J, Pock L, North JP, et al. Human polyomavirus 6 and 7 are associated with pruritic and dyskeratotic dermatoses. J Am Acad Dermatol. 2017;76(5):932-40 e3. https://doi.org/10.1 016/j.jaad.2016.11.035.

51. Canavan TN, Baddley JW, Pavlidakey P, Tallaj JA, Elewski BE. Human polyomavirus-7-associated eruption successfully treated with acitretin. Am J Transplant Off J Am Soc Transplant Am Soc Transplant Surg. 2018;18(5): 1278-84. https://doi.org/10.1111/ajt.14634.

52. Ho J, Jedrych JJ, Feng H, Natalie AA, Grandinetti L, Mirvish E, et al. Human polyomavirus 7-associated pruritic rash and viremia in transplant recipients. J Infect Dis. 2015;211(10):1560-5. https://doi.org/10.1093/infdis/jiu524.

53. Purdie KJ, Proby CM, Rizvi H, Griffin H, Doorbar J, Sommerlad M, et al. The role of human papillomaviruses and polyomaviruses in BRAF-inhibitor induced cutaneous squamous cell carcinoma and benign Squamoproliferative lesions. Front Microbiol. 2018;9:1806. https://doi.org/1 0.3389/fmicb.2018.01806

54. Rascovan N, Monteil Bouchard S, Grob JJ, Collet-Villette AM, GaudyMarqueste C, Penicaud M, et al. Human Polyomavirus-6 infecting lymph nodes of a patient with an Angiolymphoid hyperplasia with eosinophilia or Kimura disease. Clin Infect Dis. 2016;62(11):1419-21. https://doi.org/10.1093/ $\mathrm{cid} / \mathrm{ciw} 135$.

55. Hashida Y, Higuchi T, Nakajima K, Ujihara T, Murakami I, Fujieda M, et al. Human polyomavirus 6 with the Asian-Japanese genotype in cases of Kimura disease and Angiolymphoid hyperplasia with eosinophilia. J Invest Dermatol. 2020;140(8):1650-1653.e4. https://doi.org/10.1016/j.jid.2019.12.027.

56. Sadeghi M, Wang $Y$, Ramqvist $T$, Aaltonen $L M$, Pyoria $L$, Toppinen $M$, et al. Multiplex detection in tonsillar tissue of all known human polyomaviruses. BMC Infect Dis. 2017;17(1):409. https://doi.org/10.1186/s12879-017-2479-5.

57. Herberhold S, Hellmich M, Panning M, Bartok E, Silling S, Akgul B, et al. Human polyomavirus and human papillomavirus prevalence and viral load in non-malignant tonsillar tissue and tonsillar carcinoma. Med Microbiol Immunol. 2017;206(2):93-103. https://doi.org/10.1007/s00430-016-0486-6.

58. Salakova M, Koslabova E, Vojtechova Z, Tachezy R, Sroller V. Detection of human polyomaviruses MCPyV, HPyV6, and HPyV7 in malignant and nonmalignant tonsillar tissues. J Med Virol. 2016;88(4):695-702. https://doi.org/1 $0.1002 / j m v .24385$.

59. Rockett RJ, Sloots TP, Bowes S, O'Neill N, Ye S, Robson J, et al. Detection of novel polyomaviruses, TSPyV, HPyV6, HPyV7, HPyV9 and MWPyV in feces, urine, blood, respiratory swabs and cerebrospinal fluid. PLoS One. 2013;8(5): e62764. https://doi.org/10.1371/journal.pone.0062764.

60. Zheng W-Z, Wei T-I, Ma F-I, Yuan W-m, Zhang Q, Zhang Y-X, et al. Human polyomavirus type six in respiratory samples from hospitalized children with respiratory tract infections in Beijing, China. Virol J. 2015;12(1):166. https:// doi.org/10.1186/s12985-015-0390-5.

61. Delbue S, Elia F, Signorini L, Bella R, Villani S, Marchioni E, et al. Human polyomavirus 6 DNA in the cerebrospinal fluid of an HIV-positive patient with leukoencephalopathy. J Clin Virol. 2015;68:24-7. https://doi.org/10.101 6/j.jcv.2015.04.016.

62. Delbue S, Franciotta D, Giannella S, Dolci M, Signorini L, Ticozzi R, et al. Human Polyomaviruses in the Cerebrospinal Fluid of Neurological Patients. Microorganisms. 2019;8(1):16. https://doi.org/10.3390/microorganisms801001 6.

63. Siebrasse EA, Bauer I, Holtz LR, Le BM, Lassa-Claxton S, Canter C, et al. Human polyomaviruses in children undergoing transplantation, United States, 2008-2010. Emerg Infect Dis. 2012;18(10):1676-9. https://doi.org/10.32 01/eid 1810.120359.

64. Chan JF, Tee KM, Choi GK, Zhu Z, Poon RW, Ng KT, et al. First detection and complete genome sequence of a phylogenetically distinct human polyomavirus 6 highly prevalent in human bile samples. J Inf Secur. 2017; 74(1):50-9. https://doi.org/10.1016/j.jinf.2016.11.002.

65. Hashida Y, Higuchi T, Matsuzaki S, Nakajima K, Sano S, Daibata M. Prevalence and genetic variability of human polyomaviruses 6 and 7 in healthy skin among asymptomatic individuals. J Infect Dis. 2018;217(3):48393. https://doi.org/10.1093/infdis/jix516.

66. Higgins S, Nazemi A, Chow M, Wysong A. Review of nonmelanoma skin Cancer in African Americans, Hispanics, and Asians. Dermatol Surg. 2018 44(7):903-10. https://doi.org/10.1097/DSS.0000000000001547.

67. Guy GP Jr, Machlin SR, Ekwueme DU, Yabroff KR. Prevalence and costs of skin cancer treatment in the U.S., 2002-2006 and 2007-2011. Am J Prev Med. 2015;48(2):183-7. https://doi.org/10.1016/j.amepre.2014.08.036.

68. Beckervordersandforth J, Pujari S, Rennspiess D, Speel EJ, Winnepenninckx V Diaz C, et al. Frequent detection of human polyomavirus 6 in keratoacanthomas. Diagn Pathol. 2016;11(1):58. https://doi.org/10.1186/s13 000-016-0509-z.

69. Bzhalava D, Johansson H, Ekstrom J, Faust H, Moller B, Eklund C, et al. Unbiased approach for virus detection in skin lesions. PLoS One. 2013;8(6): e65953. https://doi.org/10.1371/journal.pone.0065953.

70. Kreuter A, Silling S, Dewan M, Stucker M, Wieland U. Evaluation of 4 recently discovered human polyomaviruses in primary cutaneous B-cell and T-cell lymphoma. Arch Dermatol. 2011;147(12):1449-51. https://doi.org/10.1001/a rchdermatol.2011.330

71. Du-Thanh A, Foulongne V, Guillot B, Dereure O. Recently discovered human polyomaviruses in lesional and non-lesional skin of patients with primary cutaneous T-cell lymphomas. J Dermatol Sci. 2013;71(2):140-2. https://doi. org/10.1016/j.jdermsci.2013.04.003.

72. Toptan T, Yousem SA, Ho J, Matsushima Y, Stabile LP, Fernandez-Figueras MT, et al. Survey for human polyomaviruses in cancer. JCI Insight. 2016;1(2): e85562. https://doi.org/10.1172/jci.insight.85562.

73. Mulder FJ, Klufah F, Janssen FME, Farshadpour F, Willems SM, De Bree R, et al. Presence of human papillomavirus and Epstein-Barr virus, but absence of Merkel cell polyomavirus, in head and neck Cancer of non-smokers and non-drinkers. Front Oncol. 2021;10. https://doi.org/10.3389/fonc.2020. 560434.

74. Martel-Jantin C, Filippone C, Cassar O, Peter M, Tomasic G, Vielh P, et al. Genetic variability and integration of Merkel cell polyomavirus in Merkel cell carcinoma. Virology. 2012;426(2):134-42. https://doi.org/10.1016/j.virol.2012. 01.018 .

75. Antonsson A, Bialasiewicz S, Rockett RJ, Jacob K, Bennett IC, Sloots TP. Exploring the prevalence of ten polyomaviruses and two herpes viruses in breast cancer. PLoS One. 2012;7(8):e39842. https://doi.org/10.1371/journal. pone. 0039842

76. Poluschkin L, Rautava J, Turunen A, Wang Y, Hedman K, Syrjänen K, et al. Polyomaviruses detectable in head and neck carcinomas. Oncotarget. 2018; 9(32):22642-52. https://doi.org/10.18632/oncotarget.25202.

77. Klufah F, Mobaraki G, Chteinberg E, Alharbi RA, Winnepenninckx V, Speel EJM, et al. High Prevalence of Human Polyomavirus 7 in Cholangiocarcinomas and Adjacent Peritumoral Hepatocytes: Preliminary Findings. Microorganisms. 2020;8(8):1125. https://doi.org/10.3390/microorga nisms 8081125

78. Dolei A, Pietropaolo V, Gomes E, Di Taranto C, Ziccheddu M, Spanu MA, et al. Polyomavirus persistence in lymphocytes: prevalence in lymphocytes from blood donors and healthy personnel of a blood transfusion Centre. J Gen Virol. 2000;81(Pt 8):1967-73. https://doi.org/10.1099/0022-1317-81-8-1967. 
79. Krump NA, Liu W, You J. Mechanisms of persistence by small DNA tumor viruses. Curr Opin Virol. 2018;32:71-9. https://doi.org/10.1016/j.coviro.2018. 09.002.

80. Zur HH. Oncogenic DNA viruses. Oncogene. 2001;20(54):7820-3. https://doi. org/10.1038/sj.onc.1204958.

81. Moore PS, Chang Y. Why do viruses cause cancer? Highlights of the first century of human tumour virology. Nat Rev Cancer. 2010;10(12):878-89. https://doi.org/10.1038/nrc2961.

82. Shuda M, Arora R, Kwun HJ, Feng H, Sarid R, Fernandez-Figueras MT, et al. Human Merkel cell polyomavirus infection I. MCV T antigen expression in Merkel cell carcinoma, lymphoid tissues and lymphoid tumors. Int J Cancer. 2009;125(6):1243-9. https://doi.org/10.1002/ijc.24510.

83. Houben R, Adam C, Baeurle A, Hesbacher S, Grimm J, Angermeyer S, et al. An intact retinoblastoma protein-binding site in Merkel cell polyomavirus large T antigen is required for promoting growth of Merkel cell carcinoma cells. Int J Cancer. 2012;130(4):847-56. https://doi.org/10.1002/ijc.26076.

84. Chimal-Ramírez GK, Espinoza-Sánchez NA, Fuentes-Pananá EM. Protumor activities of the immune response: insights in the mechanisms of immunological shift, oncotraining, and oncopromotion. J Oncol. 2013;2013: 835956. https://doi.org/10.1155/2013/835956.

85. Mantovani A, Allavena P, Sica A, Balkwill F. Cancer-related inflammation. Nature. 2008;454(7203):436-44. https://doi.org/10.1038/nature07205.

86. Elinav E, Nowarski R, Thaiss CA, Hu B, Jin C, Flavell RA. Inflammation-induced cancer: crosstalk between tumours, immune cells and microorganisms. Nat Rev Cancer. 2013;13(11):759-71. https://doi.org/10.1038/nrc3611.

87. Balkwill FR, Mantovani A. Cancer-related inflammation: common themes and therapeutic opportunities. Semin Cancer Biol. 2012;22(1):33-40. https:// doi.org/10.1016/j.semcancer.2011.12.005.

88. Coleman WB. Mechanisms of human hepatocarcinogenesis. Curr Mol Med. 2003;3(6):573-88. https://doi.org/10.2174/1566524033479546.

89. Di Bisceglie AM. Hepatitis C and hepatocellular carcinoma. Hepatology. 1997;26(3 Suppl 1):34s-8s. https://doi.org/10.1002/hep.510260706.

90. Brechot C, Kremsdorf D, Soussan P, Pineau P, Dejean A, Paterlini-Brechot P, et al. Hepatitis B virus (HBV)-related hepatocellular carcinoma (HCC): molecular mechanisms and novel paradigms. Pathol Biol. 2010;58(4):278-87. https://doi.org/10.1016/j.patbio.2010.05.001.

91. Skinner GR. Transformation of primary hamster embryo fibroblasts by type 2 simplex virus: evidence for a "hit and run" mechanism. Br J Exp Pathol. 1976; 57(4):361-76.

92. Prezioso C, Carletti R, Obregon F, Piacentini F, Manicone AM, Soda G, et al. Evaluation of Merkel Cell Polyomavirus DNA in Tissue Samples from Italian Patients with Diagnosis of MCC. Viruses. 2021;13(1):61. https://doi.org/10.33 90/v13010061.

93. Houben R, Grimm J, Willmes C, Weinkam R, Becker JC, Schrama D. Merkel cell carcinoma and Merkel cell polyomavirus: evidence for hit-and-run oncogenesis. J Invest Dermatol. 2012;132(1):254-6. https://doi.org/10.1038/ jid.2011.260

94. Csoboz B, Rasheed K, Sveinbjørnsson B, Moens U. Merkel cell polyomavirus and non-Merkel cell carcinomas: guilty or circumstantial evidence? APMIS. 2020;128(2):104-20. https://doi.org/10.1111/apm.13019.

95. Delbue S, Ferrante P, Provenzano M. Polyomavirus BK and prostate cancer: an unworthy scientific effort? Oncoscience. 2014;1(4):296-303. https://doi. org/10.18632/oncoscience.32.

96. Hori R, Murai Y, Tsuneyama K, Abdel-Aziz HO, Nomoto K, Takahashi H, et al. Detection of JC virus DNA sequences in colorectal cancers in Japan. Virchows Arch. 2005;447(4):723-30. https://doi.org/10.1007/s00428-0050014-3.

97. Wright CA, Nance JA, Johnson EM. Effects of tat proteins and tat mutants of different human immunodeficiency virus type 1 clades on glial JC virus early and late gene transcription. J Gen Virol. 2013;94(Pt 3):514-23. https:// doi.org/10.1099/vir.0.047902-0.

98. Behzad-Behbahani A, Klapper PE, Vallely PJ, Cleator GM, Khoo SH. Detection of $B K$ virus and JC virus DNA in urine samples from immunocompromised (HIV-infected) and immunocompetent (HIV-non-infected) patients using polymerase chain reaction and microplate hybridisation. J Clin Virol. 2004; 29(4):224-9. https://doi.org/10.1016/S1386-6532(03)00155-0.

99. Knowles WA. Discovery and epidemiology of the human polyomaviruses BK virus (BKV) and JC virus (JCV). Adv Exp Med Biol. 2006;577:19-45. https://doi. org/10.1007/0-387-32957-9_2.

100. Drop B, Strycharz-Dudziak M, Kliszczewska E, Polz-Dacewicz M. Coinfection with Epstein-Barr Virus (EBV), Human Papilloma Virus (HPV) and Polyoma BK
Virus (BKPyV) in Laryngeal, Oropharyngeal and Oral Cavity Cancer. Int J Mol Sci. 2017:18(12):2752. https://doi.org/10.3390/ijms18122752.

101. Blacklow NR. Potentiation of an adenovirus-associated virus by herpes simplex virus type-2-transformed cells. J Natl Cancer Inst. 1975;54(1):241-4. https://doi.org/10.1093/jnci/54.1.241.

102. Meier AF, Fraefel C, Seyffert M. The Interplay between Adeno-Associated Virus and its Helper Viruses. Viruses. 2020;12(6):662. https://doi.org/10.3390/ v12060662.

103. Heilbronn R, Albrecht I, Stephan S, Bürkle A, Zur Hausen H. Human cytomegalovirus induces JC virus DNA replication in human fibroblasts. Proc Natl Acad Sci U S A. 1993;90(23):11406-10. https://doi.org/10.1073/pnas. 90.23 .11406

104. Fraase K, Hart J, Wu H, Pang X, Ma L, Grant F, et al. BK virus as a potential co-factor for HPV in the development of cervical neoplasia. Ann Clin Lab Sci. 2012:42(2):130-4

105. Comar M, Bonifacio D, Zanconati F, Di Napoli M, Isidoro E, Martini F, et al. High prevalence of BK polyomavirus sequences in human papillomavirus16-positive precancerous cervical lesions. J Med Virol. 2011;83(10):1770-6. https://doi.org/10.1002/jmv.22184.

106. Borchert S, Czech-Sioli M, Neumann F, Schmidt C, Wimmer P, Dobner T, et al. High-affinity Rb binding, p53 inhibition, subcellular localization, and transformation by wild-type or tumor-derived shortened Merkel cell polyomavirus large T antigens. J Virol. 2014;88(6):3144-60. https://doi.org/1 $0.1128 / \mathrm{JVI} .02916-13$

107. Sullivan CS, Pipas JM. T antigens of simian virus 40: molecular chaperones for viral replication and tumorigenesis. Microbiol Mol Biol Rev. 2002;66(2): 179-202. https://doi.org/10.1128/MMBR.66.2.179-202.2002.

108. DeCaprio JA, Ludlow JW, Figge J, Shew JY, Huang CM, Lee WH, et al. SV40 large tumor antigen forms a specific complex with the product of the retinoblastoma susceptibility gene. Cell. 1988;54(2):275-83. https://doi.org/1 $0.1016 / 0092-8674(88) 90559-4$.

109. Sheng Q, Denis D, Ratnofsky M, Roberts TM, DeCaprio JA, Schaffhausen B. The DnaJ domain of polyomavirus large $T$ antigen is required to regulate Rb family tumor suppressor function. J Virol. 1997;71(12):9410-6. https://doi. org/10.1128/JVI.71.12.9410-9416.1997.

110. Wu JH, Simonette RA, Nguyen HP, Rady PL, Tyring SK. Molecular mechanisms supporting a pathogenic role for human polyomavirus 6 small T antigen: protein phosphatase $2 \mathrm{~A}$ targeting and MAPK cascade activation. J Med Virol. 2017:89(4):742-7. https://doi.org/10.1002/jmv.24688.

111. Janssens V, Goris J, Van Hoof C. PP2A: the expected tumor suppressor. Curr Opin Genet Dev. 2005;15(1):34-41. https://doi.org/10.1016/j.gde.2004.12.004

112. Howley PM, Pfister HJ. Beta genus papillomaviruses and skin cancer. Virology. 2015;479-480:290-6. https://doi.org/10.1016/j.virol.2015.02.004.

\section{Publisher's Note}

Springer Nature remains neutral with regard to jurisdictional claims in published maps and institutional affiliations.

Ready to submit your research? Choose BMC and benefit from:

- fast, convenient online submission

- thorough peer review by experienced researchers in your field

- rapid publication on acceptance

- support for research data, including large and complex data types

- gold Open Access which fosters wider collaboration and increased citations

- maximum visibility for your research: over $100 \mathrm{M}$ website views per year

At BMC, research is always in progress.

Learn more biomedcentral.com/submissions 